\title{
Recovery of cheese whey, a by-product from the dairy industry for use as an animal feed
}

\begin{abstract}
The objective of this research was to determine whether whey, a by-product from a cheese manufacturing process, could be used as an animal Feed. Sheep were judged as a suitable alternate ruminant to carry out preliminary trials to allow scientific investigation of the suitability and the value of the whey. Also these trials were used to demonstrate to farmers the potential benefit of using whey in their feeding diets and to answer any preliminary concerns. Benefits and achievements results it could be concluded that for farms: Whey replaces $100 \%$ of water intake at the farm, Whey provides a low-cost alternative to liquid feeds, at a fraction of the cost (less than $10 \%$ of molasses), 19 liters of liquid whey permeate can replace the same amount of energy and protein as provided by $2.4 \mathrm{~kg}$ of a $88 \%$ crude protein feed mix/roughage, Roughage intake per $\mathrm{kg}$ gain can be reduced from $3 \mathrm{~kg}$ to $1 \mathrm{~kg}$ (75\% weighing (200kg/head) being fattened to $400 \mathrm{~kg}$, an additional income of $\$ 30 / \mathrm{head}$ will be achieved, Whey can improve the feed palatability, texture, and dust control of feedlot rations. It provides a balanced nutrition of energy, protein, minerals, and a safety factor to compensate for poor or variable quality diets, being a pump able supplement, whey can save on feeding overheads as it requires less labour and feeding and mixing equipment, and can provide an economic and convenient method to feed urea supplements, vitamins, minerals and feed additives. For Dairy Factories: $100 \%$ recovery of a previously wasted by-product which needs no development requirements and low capital investment, Eliminating or reducing whey disposal at the factory has significantly reduced the environmental pollution, namely Biochemical Oxygen Demand (BOD), Chemical Oxygen Demand (COD), Total Suspended solids (TSS), Total Dissolved solids (TDS), oil and grease.
\end{abstract}

Volume 6 Issue 5 - 2017

\author{
El-sayed El-Tanboly, Mahmoud El-Hofi, \\ Khorshid \\ Dairy Department, National Research Center, Egypt
}

Correspondence: El-sayed El-Tanboly, Dairy Department, National Research Center, Cairo, Egypt, EmailTanboly1951@yahoo.com

Received: February 14, 2017| Published: June 06, 2017

\section{Introduction}

Whey is the by-product of cheese or casein production, it is of relative importance in the dairy industry due to the large volumes produced and the nutritional composition. Worldwide whey production is estimated at around 180 to $190 \times 10^{6}$ ton/year; of this amount only $50 \%$ is processed. ${ }^{1}$ Approximately $50 \%$ of worldwide cheese-whey (CW) production is treated and transformed into various foods and feed products. About half of this amount is used directly in liquid form, $30 \%$ as powdered cheese-whey, $15 \%$ as lactose and its byproducts and the rest as cheese whey- protein concentrates. ${ }^{2}$ A total of $40 \times 10^{6}$ tons/ year of whey is produced in the European Union; ${ }^{3}$ the annual surplus of whey is $13 \times 10^{6}$ tons, containing about 619,250 tons of lactose. Nowadays this surplus is not utilized for further production of lactose; consequently, whey disposal represents a serious problem from both an economical and an environmental point of view. On the contrary, recovery of whey components and/or use of whey as fermentation medium may be advantageous not only for the environment but also for a sustainable economy. ${ }^{4,5}$

Whey contains more than half of the solids present in the original whole milk, including whey proteins $(20 \%$ of the total protein) and most of the lactose, water-soluble vitamins and minerals. Cheese-whey represents about $90-95 \%$ of the milk volume and retains about $55 \%$ of milk nutrients. The most abundant of these nutrients are lactose (4.5$5.0 \% \mathrm{w} / \mathrm{v})$, soluble proteins $(0.6-0.8 \% \mathrm{w} / \mathrm{v})$, lipids $(0.4-0.5 \% \mathrm{w} / \mathrm{v})$ and mineral salts $\left(8.0-10.0 \mathrm{w} / \mathrm{v}\right.$ of dried extract) ${ }^{6,7}$ Consequently, whey can be considered a valuable by-product with several applications in the food and pharmaceutical industries. Sometimes whey permeate, obtained from ultrafiltration step, has been used as fermentation medium; in this case, both the management options are applied. The ultrafiltration process produces a whey permeate rich in lactose (about $80 \%$ of the original lactose in milk) new technologies have been developed (using nanofiltration or reverse osmosis) for concentration of the lactose which can be applied in the sweet industry or in pharmaceutical fermentation procedures. ${ }^{8}$ In addition to lactose, whey permeate containing other nutrients essential for microbial growth; so the possibility to use it as a fermentation medium to obtain high value products represents an interesting opportunity ${ }^{4}$ which must not be neglected. Moreover, whey permeate is an attractive source of oligosaccharides for potential application in human nutrition. ${ }^{9}$ Among the different possibility of whey valorization.

Under the SEAM Project, whey was recovered from cheese manufacturing in Misr Company for Dairy and Food, Damietta, Egypt for use as a supplementary animal feed.

\section{The factory}

The factory is one of the largest public sector dairy producers in Egypt. It was built in 1966 and today has a workforce of 512. The production is seasonal and includes a wide variety of products. The factory processes raw milk $(8,250$ ton/year) to produce white cheese (1,250ton/year), hard cheese (850ton/year), processed cheese (700ton/ year), ghee (300ton/year) and Mish (200ton/year)

\section{Whey generation}

Whey, a liquid by-product originating from cheese manufacture which constitutes the greater part of the resulting pollution loads, 
mainly biological (Table 1). Waste discharges generated from the factory primarily consist of product losses, wash waters and whey, a liquid by-product originating from cheese manufacture which constitutes the greater part of the resulting pollution loads, mainly biological. The factory produces substantial quantities of whey's of different characteristics:

i. Sweet whey is generated from hard cheese making during the seasonal swing for Grade a milk production from December to May. From 6ton of milk processed there are approximately 5ton of sweet whey for each 1 ton of hard cheese.

ii. Whey permeate is generated throughout the year from the ultrafiltration process of white cheese production. From 2.5ton of milk processed there are approximately 1.5 ton of permeate for each 1 ton of cheese.

Table I Analysis of whey and final effluent.

\begin{tabular}{lllll}
\hline \multirow{2}{*}{ Characteristics } & \multicolumn{2}{l}{ Whey Characteristic } & & Effluent \\
\cline { 2 - 4 } & Sweet & De proteinised & Permeate & With whey \\
\hline Volume (m3/year) & 4,250 & 4070 & 1,900 & 183000 \\
BOD (ppm) & 73,300 & 57400 & 55,000 & 2300 \\
COD (ppm) & 90,400 & 73580 & 72,400 & 4050 \\
TSS (ppm) & 12,350 & 2010 & 2,800 & 540 \\
TDS (ppm) & 49,280 & 47810 & 4,460 & 2290 \\
Oil \& Grease (ppm) & 14,000 & 3000 & 1,250 & 420
\end{tabular}

BOD (ppm), biochemical oxygen demand (Part per million); COD (ppm), chemical oxygen demand (Part per million); TSS (ppm), total suspended soilds (Part per million);TDS, (ppm) total dissolved soilds (Part per million)
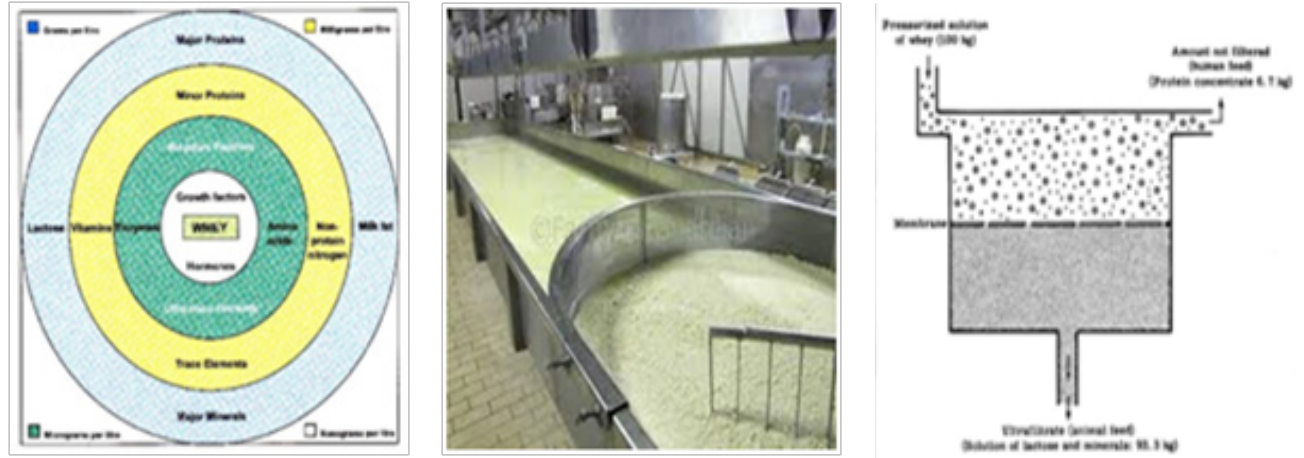

Figure I Whey generated from hard cheese making, white cheese Ultra-filtration process and collected for use as animal feed.

\section{Pollution prevention opportunities}

Whey dumped into the factories disposal system has very high pollution loads caused by the protein and carbohydrates (Figure 1).

The factory disposes its final effluent into the cities sewers without treatment. Analysis of whey and of the final effluent is summarized in Table 1. Equivalent to the daily domestic waste produced by 18,000 people. In addition to being a high environmental pollutant, disposal of the nutrient rich whey is a loss to the factory. Whey is a valuable source of carbohydrates, a good supply of energy, and contains high quality protein and minerals.

\section{Nutrient recovery}

Sweet whey is processed to recover 0.25 ton/day of fat by centrifugation and 0.25 ton/day of protein by settling. This volume is however reduced by only $4 \%$ and the factory is still left with a huge quantity of de-proteinised whey to dispose of or further process.

\section{Whey processing}

For the factory, options like whey drying, concentration and fractionation are too costly, and demand investment in technology and development requirements. As an example, it is not economically viable for the factory to invest in a large commercial drying facility which will cost close to LE1 million to produce dry whey products for human use as the market for such products does not presently exist in Egypt.

\section{End-of-pipe-treatment}

Effluent containing whey, whether treated alone or in conjunction with other processing or/and domestic wastes cause extensive treatment problems. In addition to processing high put rescibility, whey may present problems of $\mathrm{pH}$ control in biological treatment processes The factory is in the process of installing an industrial wastewater treatment plant which if whey was included would have to be large and costly, consisting of primary settling, multistage packed 
tower trickling filters, final settling, coagulation, chlorination, and sludge digestion. Finding an alternative to use the whey could reduce the environmental risks, costs and difficulties associated with end-ofpipe treatment.

\section{Cleaner production application}

The use of liquid whey as an animal feed for ruminants has been implemented through the Cleaner Production Demonstration Projects of the SEAM Project and is briefly outlined below.

\section{Materials and methods}

Substantial effort was devoted to the applicability of recovering whey for ruminant feed and the methodology of demonstrating its suitability. Important issues that were addressed included: (Figure 2)

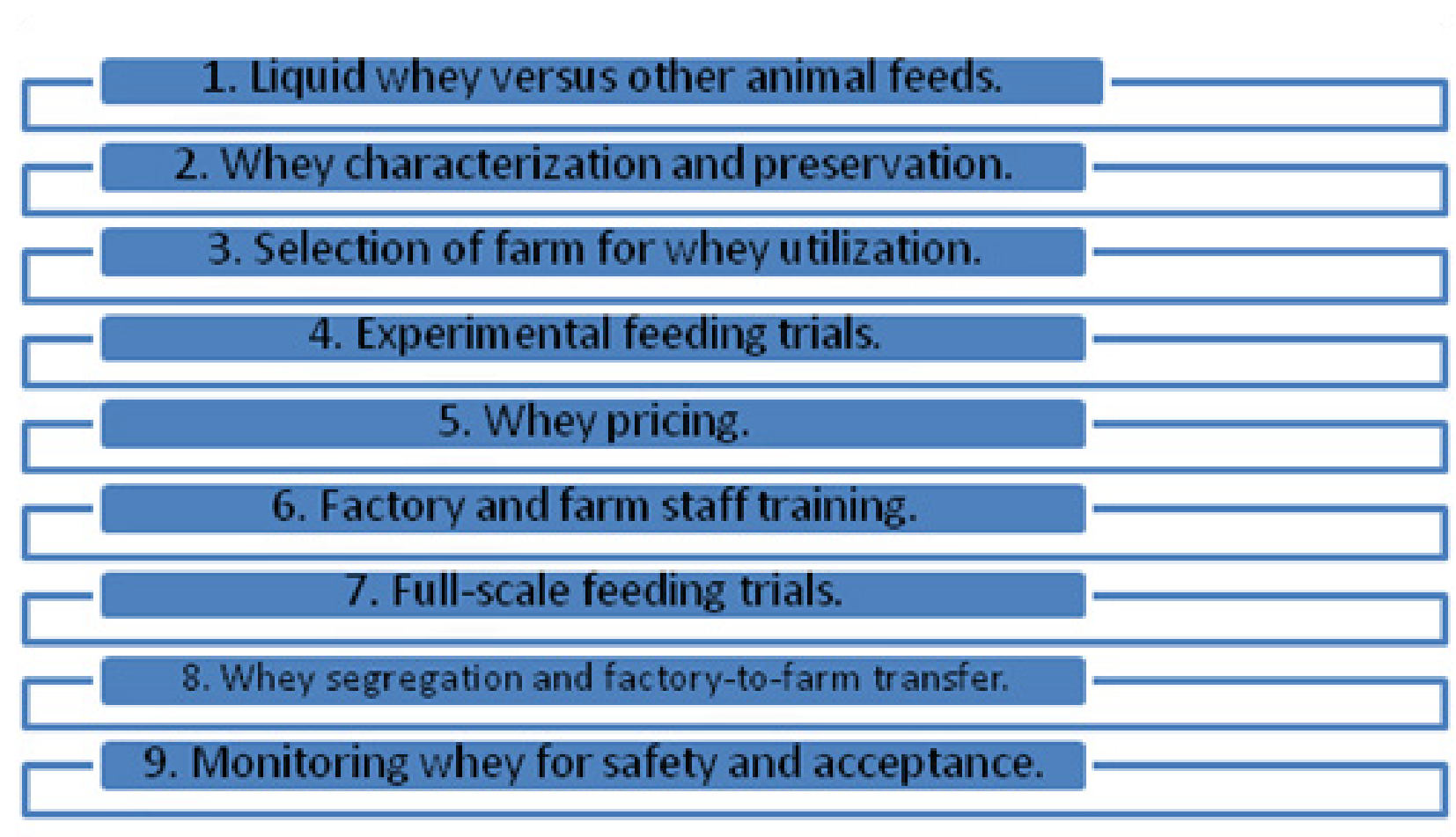

Figure 2 Methodology and Application of recovering whey for ruminant feed.

\section{Results and discussions}

\section{Liquid whey versus other animal feeds}

In Egypt, cane and beet molasses has been used for many years as the basis for liquid feeds for ruminants. Like molasses liquid whey can be a carrier of non-protein nitrogen components such as urea or ammonium salts to make crude protein supplements. Unlike molasses whey has a good supply of minerals especially calcium and phosphorus. Whey has seldom been used in feedstock operations and surveys where carried to evaluate the acceptance of Egyptian farmers. General interest in a low or no cost high quality supplement was concurrent and the common concerns were related to safety, storage life, and nutritional value and feed efficiency. These concerns were addressed in detail and are discussed below.

\section{Whey characterization and preservation}

Physical, chemical, and nutritional analyses of the whey were undertaken (Table 2). For comparison, molasses characteristics were also examined. Whey characteristics were assessed against limit values which might cause possible animal health problems. Whey feeding problems may occur if:

$$
\text { i. } \mathrm{pH} \text { values of whey drop below } 4.5 \text { or exceed 8.5. }
$$

ii. Total microbial count exceeds $\left(1 \times 10^{6} / 100 \mathrm{ml}\right)$.

iii. Total coli form count exceeds $(1 / 100 \mathrm{ml})$ for calves and $(30 / 100 \mathrm{ml})$ for cows. Storage life of whey may be affected by both time and temperature. Temperature increase may cause problems and could be conducive to mould growth.

As whey becomes acidic and less palatable after being stored, keeping whey fresh was examined by cooling, pasteurizing, or by adding preservatives:

i. Permeate from ultra-filtration is pasteurized by the process itself, however hard cheese whey will require preservation if it is to be stored or delivered in hot weather conditions or to distant farms.

ii. After storing fresh whey permeate $(\mathrm{pH}$ 6.5) for 24hours, $\mathrm{pH}$ dropped to 4.8 .

iii. Time-temperature $\mathrm{pH}$ values were determined for preserving whey permeates using different concentrations of various preservatives.

It was found that formaldehyde $(0.01 \%)$ and hydrogen peroxide $(0.02 \%)$ were the most economical and effective preservatives to add, maintaining a $\mathrm{pH}$ value above 6 even at high temperatures reachington of whey, respectively. 
Table 2 Whey characteristics

\begin{tabular}{|c|c|c|c|}
\hline Characteristics & $\begin{array}{l}\text { Sweet } \\
\text { Whey }\end{array}$ & Whey Permeate & $\begin{array}{l}\text { Cane } \\
\text { Molasses }\end{array}$ \\
\hline \multicolumn{4}{|l|}{ Chemical Composition (as fed) } \\
\hline Specific Gravity (kg/litre) & 1.025 & 1.03 & 1.262 \\
\hline $\mathrm{pH}$ & 6.4 & 6.55 & 5.5 \\
\hline Titratable Acidity & 0.05 & 0.089 & $\mathrm{n} / \mathrm{a}$ \\
\hline Water (\%) & 91.95 & 94.45 & 25 \\
\hline Dry Matter DM (\%) & 8.05 & 5.55 & 75 \\
\hline Solids Not-Fat (\%) & 7.55 & 5.55 & 75 \\
\hline Fat (\%) & 0.5 & 0 & 0.1 \\
\hline Crude Protein CP (\%) & I.I & 0.25 & 3.2 \\
\hline Soluble Carbohydrates (\%) & 5.2 & 4.9 & 62.75 \\
\hline Total Ash (\%) & 0.52 & 0.5 & 9.2 \\
\hline \multicolumn{4}{|c|}{ Nutritient Content (Dry Matter Basis) } \\
\hline Total Nitrogen (\%) & 1.3 & 0.26 & 0.66 \\
\hline Non Protein Nitrogen (\%) & 0.34 & 0.24 & - \\
\hline Calcium (\%) & 0.058 & 0.055 & 0.89 \\
\hline Phosphorus (\%) & 0.052 & 0.045 & 0.082 \\
\hline Net Energy Lactation (Mcal/lb) & 0.9 & 0.85 & 0.65 \\
\hline Total Digestible Energy (Mcal/lb) & 1.86 & 1.7 & 1.4 \\
\hline \multicolumn{4}{|l|}{ Gate Price (LE/ton) } \\
\hline Gate Price (LE/ton) & $\mathrm{n} / \mathrm{a}$ & $n / a$ & 220 \\
\hline
\end{tabular}

\section{Selection of farm for whey utilization}

Damietta Governorate is the heart of factory enjoys the advantage of being close to many dairy farms. Field reviews were conducted to find suitable farms to receive the whey and criteria were developed for such selection. The Animal Wealth Society Farm, located 10km away from the factory, was chosen out of seven nearby medium to large farms in view of its location, size, facilities, and management capabilities. The farm has 725 head of Holestein, Brown Swiss and Friesian breeds managed under a sophisticated dairy feedlot operation where all cows are penfed and breeds are carefully evaluated for milk yield and diets adjusted according to yield. Municipal water is the only liquid source, and 60ton are used daily amounting to an annual cost of LE13, 200. 1,825ton/year of concentrate mix feed valued at LE1 million, and 900ton of roughage valued at LE360,000 are fed annually at a daily rate of $7 \mathrm{~kg}$ and $3 \mathrm{~kg}$ per head, respectively.

\section{Experimental feeding trials}

Sheep were judged as a suitable alternate ruminant to carry out preliminary trials to allow scientific investigation of the suitability and the value of the whey. Also these trials were used to demonstrate to farmers the potential benefit of using whey in their feeding diets and to answer any preliminary concerns. Eight week experiments for a six pen trial of five sheep per pen were undertaken in which sheep 8-10 months old, weighing 37-39kg were fed free choice six different liquid feeds next to ration components of roughage (berseem hay, DM: 87.4\%, CP: 13.6\%) and mix feed (cotton seed meal; yellow corn; wheat bran; salt; limestone, DM: $89.5 \%$, CP: $17.3 \%)$.]

In some diets protein was provided in the form of liquid urea mixed in as part of either the liquid whey permeates the molasses or as part of their mixture. Feed consumption and feed efficiency data is represented below (Table 3) (Table 4). The result of the trials indicates that liquid permeate: Can be fed satisfactory even without being supplemented with nitrogen, can provide a good quality liquid intake and compares favorably to traditionally used liquid feeds such as molasses and when used alone it yielded the highest feed efficiency (i.e. kilogram whey fed per kilogram live weight gain) in comparison to other diets. 
Table 3 Growth data (64days)

\begin{tabular}{|c|c|c|c|c|c|}
\hline \multirow{2}{*}{ Liquid Feed } & \multicolumn{5}{|c|}{ Average live weight per animal $(\mathrm{Kg})$} \\
\hline & Initial weight & Final weight & 64-day gain & 64-day gain \% & Daily gain \\
\hline Water (as control) & 38.14 & 48.6 & 10.46 & 28.22 & 0.163 \\
\hline Permeate (I00\%) & 39.1 & 52.4 & 13.3 & 33.93 & 0.208 \\
\hline Permeate $(95.5 \%)+$ Urea $(0.5 \%)$ & 38.5 & 49.5 & II & 28.89 & 0.172 \\
\hline Molasses(80\%) & 37.6 & 50.6 & 13 & 34.65 & 0.203 \\
\hline Molasses $(7.5 \%)+$ Urea $(0.5 \%)$ & 38.7 & 50 & 11.3 & 28.95 & 0.177 \\
\hline Permeate $(50 \%)+$ Molasses $(4 \%)+$ Urea $(0.5 \%)$ & 38.7 & 49.4 & 10.7 & 27.68 & 0.167 \\
\hline
\end{tabular}

Table 4 Feed consumption and efficiency

\begin{tabular}{|c|c|c|c|c|}
\hline \multirow{3}{*}{ Liquid feed } & \multicolumn{4}{|c|}{ Average daily feed intake (Kg) } \\
\hline & \multicolumn{2}{|c|}{ Dry matter } & \multirow{2}{*}{-Liquid } & \multirow[t]{2}{*}{$\begin{array}{l}\text { Feed efficiency (Feed/ } \\
\text { Gain) }\end{array}$} \\
\hline & Mix feed & Roughage & & \\
\hline Water (as control) & 1.1 & 0.52 & 2.7 & 9.91 \\
\hline Permeate (I00\%) & I.I & 0.46 & 3.95 & 7.51 \\
\hline Permeate $(95.5 \%)+$ Urea $(0.5 \%)$ & 1.07 & 0.47 & 3.68 & 8.94 \\
\hline Molasses (80\%) & 1.1 & 0.51 & 4.23 & 9.16 \\
\hline Molasses $(7.5 \%)+$ Urea $(0.5 \%)$ & 1.1 & 0.51 & 4.31 & 7.96 \\
\hline Permeate $(50 \%)+$ Molasses $(4 \%)+$ Urea $(0.5 \%)$ & I.I & 0.51 & 5.34 & 9.66 \\
\hline
\end{tabular}

\section{Whey pricing}

Based on the feeding trials, an algorithm was developed to price the real nutritional benefit of the liquid whey to the farmer in terms of feed efficiency. The value of liquid whey was best determined by comparing its cost to the cost of protein and energy from other sources such as roughage and mix feed. Based on a direct cost-consumption comparison the true value of fresh liquid permeate was determined to be LE70/ton. To make whey an attractive alternative for farmers, dairy factories may start by providing it for either the cost of hauling, the cost of water or at a very low price. After proving advantageous for the farmer, a price tag may be gradually attached over a period of time.

\section{Factory and farm staff training}

A training programmed for 5 factory production staff and 2 farm operators was completed. Training objectives were to ensure that the two parties fully understood the elements of using whey as animal feed. This included training on whey control procedures, whey handling, cleaning activities, record keeping and taking measurements for whey and animal monitoring.

\section{Full-scale feeding trials.}

The end results of the experimental trials has shown that feeding permeate can provide an effective diet and as such experiments were up-scaled to the farm in Damietta. Feeding liquid whey is being devised for full scale application where whey is fed to both dry and lactating cows in which cows are monitored on a weekly basis for feed intake, and live weight gain or milk production.

\section{Whey segregation and factory-to-farm transfer}

Emphasis has been placed on developing an economical and easily used factory-to-farm distribution system. This covers transferring the whey from the source point in the factory to the drinking basins at the farm as explained below.

Due to factory layout limitations it was difficult to develop a least-cost system consisting of mobile hoses and a portable pump and therefore whey had to be segregated and a stationary transfer system had to be designed. Investment (LE49, 850) in corrosion resistant equipment consisting mainly of piping, pumps and collection tanks with a transfer capacity of $\left(10 \mathrm{~m}^{3} /\right.$ hour $)$ was required. Whey is delivered to an outside platform tank and pumped onto a lorry for transfer to the farm. Originally, in the farm water was pumped from the elevated piping network. Since whey can completely replace water intake provided the whey supply is consistent, it is unnecessary to have a separate water drinking system. Thus, whey can be pumped continuously from a storage tank through pipelines at no cost to the farm. 


\section{Monitoring whey for safety and acceptance}

LE8, 500 was invested in portable $\mathrm{pH}$ meters and thermometers to allow continuous monitoring of the whey at 4 key locations: at factory gate, during transfer to farm, at farm gate, and in farm drinking basins. Upon whey arrival in the farm, it is tested for $\mathrm{pH}$ and if accepted it is delivered to the concrete drinking basins. Farm gate whey acceptance criteria were based on a $\mathrm{pH}$ value of 5.5 to 6 . In the farm drinking basins, $\mathrm{pH}$ is not allowed to drop below 4-4.5 and is disposed to the drain within 24 hours of being generated at the factory.

\section{Economics}

Costs associated with whey feeding were mainly segregating, setting up and running a factory-to-farm trucking and transfer system. Financial benefits to the factory are mainly the reduction in whey disposal and treatment costs in addition to potential revenues from selling the whey to the farmers. Farmers can enjoy substantial direct savings in feeding costs and increased animal productivity. Cost benefits for both the factory and the farm are presented below based on a 3-year marketing plan. The 3-year target price of whey is LE15/ ton, $78 \%$ below its true value and at $6.8 \%$ of molasses price.

\section{Benefits and achievements}

\section{For farms}

i. Whey replaces $100 \%$ of water intake at the farm.

ii. Whey provides a low-cost alternative to liquid feeds, at a fraction of the cost (less than $10 \%$ of molasses).

iii. 19 liters of liquid whey permeate can replace the same amount of energy and protein as provided by 2.4 kilogram of a $88 \%$ crude protein feed mix/roughage.

iv. Roughage intake per $\mathrm{kg}$ gain can be reduced from $3 \mathrm{~kg}$ to $1 \mathrm{~kg}$ ( $75 \%$ weighing $(200 \mathrm{~kg} / \mathrm{head})$ being fattened to $400 \mathrm{~kg}$, an additional income of LE200/head will be achieved.

v. Whey can improve the feed palatability, texture, and dust control of feedlot rations. It provides a balanced nutrition of energy, protein, minerals, and a safety factor to compensate for poor or variable quality diets.

vi. Being a pump able supplement, whey can save on feeding overheads as it requires less labour and feeding and mixing equipment, and can provide an economic and convenient method to feed urea supplements, vitamins, minerals and feed additives.

\section{For dairy factories}

i. $100 \%$ recovery of a previously wasted by-product which needs no development requirements and low capital investment.

ii. Eliminating or reducing whey disposal at the factory has significantly reduced the environmental pollution, namely BOD, COD, TSS, TDS, and Oil and Grease by 415ton, 522ton , 58ton, 218ton, and 62ton, respectively. This has allowed the factory to move towards compliance with industrial wastewater discharge Law 93. Discharge volume reduced by $5970 \mathrm{~m} 3 /$ year.

iii. Up to $25 \%$ reduction in wastewater disposal and end of-pipe treatment requirements costs.

\section{Recommendations and tips}

i. For dairy factories it is most cost effective to return whey to farmers on its milk procurement routes. ii. Significant attention should be given to quality assurance when handling whey to assure minimum contamination, extended storage life and satisfactory feeding performance are maintained.

iii. Fresh delivery of whey from the dairy factory to farms is highly recommended and if whey storage is necessary it is recommended to use a preservative such as hydrogen peroxide.

iv. Formaldehyde is not recommended in feeding lactating cows because it is carried over into the milk.

v. Corrosion-resistant equipment should be used as the acids in the whey can quickly rust and corrode metals or pit concrete.

vi. Stainless steel pipes and tanks or fiber-glass-lined tanks are recommended for transfer, feeding and storage.

vii. The piping network must be thoroughly cleaned at least once a week between whey deliveries to avoid microbial contamination and off flavours in the whey.

viii. Whey fed to animals should be introduced over a few weeks period to avoid digestive disorders manifested by diarrhea, bloat, depressed appetite or reduced productivity. This can be achieved by starting with a blend of $20 \%$ whey and $80 \%$ water, then increasing the whey proportion by $20 \%$ every 3 days until diet is of full strength whey. Digestive disorders can also be avoided by sustaining a fresh supply of good quality whey, not allowing animals to run out of whey for extended periods of time, and feeding at least 3-4 $\mathrm{kg}$ of roughage per head daily.

ix. The amount of whey offered should be adequately controlled to prevent exhaustive consumption of whey in a short time and thus avoiding possible bloat problems.

$x$. The accumulation of flies attracted to the whey was observed as the only operational difficulty, and may present aesthetic rather than health concerns.

xi. Fly control measures are recommended.

\section{Conclusion}

From the foregoing results, it could be recommended to use whey, a by-product from a cheese manufacturing process, could be used as an animal feed.

\section{Acknowledgements}

None.

\section{Conflict of interest}

The author declares no conflict of interest.

\section{References}

1. Baldasso C, Barros TC, Tessaro IC. Concentration and purification of whey proteins by ultrafiltration. Desalination. 2011;278:381-386.

2. Spalatelu C. Biotechnological valorization of whey. Innovative Romanian Food Biotechnology. 2012;10:1-8.

3. Koller M, Bona R, Braunegg G, et al. Production of Polyhydroxyalkanoates from Agricultural Waste and Surplus Materials. Biomacromolecules. 2005;6(2):561-565.

4. Panesar, PS, Kennedy JF, Gandhi DN, et al. Bioutilisation of whey for lactic acid production. Food Chemistry. 2007;105(1):1-14.

5. Jelen P, H Roginski JW Fuquay, PF Fox. Whey processing. Encyclopedia of dairy sciences Academic Press; 2003. p. 2739-2751 London. 
6. Kosikowski FV, Wzorek W. Whey wine from concentrates of reconstituted acid whey powder. J Dairy Sci. 1977;60(12):1982-1986.

7. Kosikowski FV. Whey utilization and whey products. J Dairy Sci. 1979;62(7):1149-1160.

8. Atra R, Vatai G, Bekassy-Molnar E, et al. Investigation of ultra- and nanofiltration for utilization of whey protein and lactose. Journal of Food Engineering. 2005;67(3):325-332.

9. Barile D, Tao N, Lebrilla CB, et al. Permeate from cheese whey ultrafiltration is a source of milk oligosaccharides. Int Dairy J. 2009;19(9):524-530.
10. Chiara Mollea, Luca Marmo, Francesca Bosco. Valorisation of Cheese Whey, a By-Product from the Dairy Industry; 2013.

11. Prazeres AR, Carvalho F, Rivas J. Cheese whey management:A review. J Environ Manage. 2012;110:48-68

12. Spălățelu (Vicol). Valorization of cheese whey. Biotechnological Innovative Romanian Food Biotechnology. 2012;10:1-8. 